\title{
Reggae, Rasta and the role of the deejay in the black British Experience
}

\author{
William 'Lez’ Henry
}

\begin{abstract}
When me and Culture (Smiley) was chatting in the 80s we were talking about what life was like for us as black youths. We are the best ones to talk about how Reggae deals with our situation, because we are what the music is about. (Asher Senator, author's interview, 1999)
\end{abstract}

\section{Introduction}

In concordance with the British deejay Asher Senator's statement, the argument presented here is a historical take on British Sound System ${ }^{1}$ and deejay ${ }^{2}$ culture, demonstrating how black youth in the late 70 s to early 80 s documented and articulated their experiences of racial discrimination in a unique and highly intelligent fashion. By recovering this aspect of British black oral history a new empirical discussion will be forthcoming; detailing particular identity formations around recognisably black cultural forms, which provide a mechanism for coping with the multiple and ever-present forms of popular racism. For this reason I present an account of what happens within a space where those that are excluded from a public sphere $^{3}$ which renders them voiceless, do in fact engage in discussions that concern very public issues from an alternative black perspective. These discussions and articulations are voiced within the unique cultural sphere of the Reggae-dancehall event and surrounding cultural milieu which are an 'alternative public sphere' (Gilroy, 1987). This 'alternative public sphere', which is heavily influenced by Jamaican, Rastafarian ${ }^{4}$ and Garveyite ${ }^{5}$ doctrine, enables those excluded from presenting their views in the wider public arena, a 
space within which to do so. Of equal importance is to gain an historical understanding of the language of articulation that has been chosen by black youth in Britain Patwa ${ }^{6}$, which is paramount here because the genesis of the form cannot be fully appreciated without it. Moreover, the documenting of this 'hidden' history has been assisted by the fact that much of it is contained on live 'Session-tapes', which are Sound System cassette ${ }^{7}$ and videotapes that were disseminated across what Paul Gilroy dubs the 'black Atlantic' (Gilroy, 1993a). For this reason I will present some of the historical links that are drawn from the Chattel Slave experience which are crucial to understanding this verbal art form. By doing so I will be able to detail what life was like for black youth during this historical moment using their own perspectives, contrasted with interviews I have conducted with many of these performers for several years. Moreover it will become apparent that the Reggae dancehall becomes a site where ordinary people get to air and discuss their innermost concerns and engage in cultural and political dialogues, publicly; largely without fear of reprisal and sanction from the state.

\section{Black Youth under 'endless pressure'}

From you skin is black you is ah struggling man, all over the world not just England, we have many enemies including Babylon, cos we can't turn to them when we want protection, in ah Parliament we have no representation, cos not many blacks ah turn politician, when they do them is the tool of the politician, cos in ah parliament you find the most corruption, the National Front practice racialism, and say them want all blacks out of England, 
but me know say them grudge my complexion,

cos as the sun start shine, them buy lotion,

and boast to them friend "I've got a lovely sun tan,

me glad say me born as a black man.

(Lezlee Lyrix, Ghettotone Sound System, 1983)

In a major study on the effects of West Indian culture on black youths in Britain, during the 'crisis' period of the 1970s, the Jamaican Ken Pryce offered an 'insider' perspective entitled Endless Pressure (1979/1986). When I first read this account of black life as a mature student in 1994, I recalled the above $\operatorname{lyric}^{8}$ that I (Lezlee Lyrix) used to chat on Ghettotone Sound System and realised that the political take I have on black life that was inspired by the kinds of debates and discussions we partook in, within the Reggae-dancehall space, is absent from Pryce's account. Pryce focuses on what he regards as the differences in 'lifestyle' choices between the parental generation and their children who either came from the Caribbean or were British born. He attributes the differences in these 'lifestyles' to the instability of the West Indian family structure, out of which it is the 'young who invariably suffer'. Pryce forcefully argues throughout his text that the antisocial 'culture' that is embraced by 'teenyboppers' (black youth), is spawned from their precarious positioning within the 'fragmented social framework' (Pryce, 1979:119) that is representative of 'West Indian family life'. He argues this is because there is a 'lack of group identity' and no 'communal form of group life based on a sense of collective interdependence and mutual obligation among kinsmen' (Pryce, 1979:119). These claims, that overlook what occurred historically in the Caribbean with regard to the formulation of complex patterns of kinship ${ }^{9}$ etc., became a firm enough basis from which to claim that this 'fragmented social framework' ensures that 'West Indian family life' cannot hope to cater for its young people, whether in Britain or the Caribbean. Consequently, to alleviate their suffering, black British youth invariably partake 
in a 'culture' of street crime, which can be rooted back to 'a minority and deviant subculture within the West Indies itself' (Lea and Young, 1984:127).

Arguably, such explanations fit neatly into 'sub' types of cultural theory that measure black 'settlement' or discontentment according to an idealised white 'standard of civilised behaviour', which is why Gilroy (1993b) argues 'England's black settlers are forever locked in the bastard culture of their enslaved ancestors, unable to break out into the 'mainstream' alternative" (Gilroy, 1993b:25). The suggestion is an attempt is made by the parental generation to embrace or aspire to these 'standards' of Britishness because they represent for them the culture of their 'mother country'. More importantly they expect their children, especially the British born, to 'naturally' do the same, more so when you consider that they are being socialised and educated in a dominant culture where these 'standards' are the norm. When this is not forthcoming the result is intergenerational conflicts that have dire consequences for black youth due to their supposed blanket rejection of recognised 'standards of civilised behaviour'. This 'failure' on the part of black youth culminates in the inevitable scenario as they are, according to Pryce, 'instantly spat out onto the street whenever a family crisis occurs', where they embrace a 'Rasta-rudie black oriented counter-culture' (Pryce, 1979:156). Moreover due to this 'failure' to do what is 'second nature to authentic Britons', Pryce further suggests that 'teenyboppers' responded to familial and white 'rejection with rejection'. Consequently this form of 'rejection' led to the embracing of Reggae music and Rastafari because 'Reggae has decidedly criminal connotations' (Jones, 1986:56).

In fact to bolster his 'authentic' claims he further suggests that 'almost all the Reggae singers in Britain (and in Jamaica) have either been delinquents or ex-hustlers or have come from particularly impoverished backgrounds" (Pryce, 1979:154). Therefore musical affiliation is understood as a consequence of your class position within the West Indian social structure, which is then used to validate the idea that poverty and rebellion are synonymous 
with criminality. Furthermore, this 'life-style' of criminality is a direct consequence of their 'structural placement', in the lower strata of British society. There is no mention by Pryce of the fact that 'the over-determining salience of race in Britain led many migrants to close ranks regardless of class...as many...felt that all Jamaicans were in the same social class' (James, 1993:244). This explains why the migrants from the West Indies chose to 'close ranks' and because of the Jamaican numerical advantage, as well as their immediate association with a bullish Rude boy culture ${ }^{10}$ from the streets of Kingston Jamaica, it made sense to be 'Jamaican'. What this meant in the wider public arena was many things good and ill were associated with being Jamaican and more significantly this idea of being Jafacan (fake-Jamaican) was to leave a major impression, musically and style wise, on British expressive youth cultures and still does. Pryce fails to consider this aspect of black musical culture and thus traps himself within the rigidity of his dichotomisation, because he cannot see the value in these types of heterogeneous, Caribbean, group activity or their positive impact on the wider British youth experience. His theorisation of the Caribbean community in Britain will not allow for members from the other West Indian 'lifestyles' to 'play' any 'part in the music business', which again separates Jamaicans as an almost 'discrete social category'. Crucially then, although Pryce considers many of the racial and cultural aspects of the Caribbean community in Bristol, which he argues is 'pretty representative of the experience of most working-class West Indians in Britain' (Pryce, 1986:271); he largely views these 'lifestyles' as types of 'false consciousness'. 'Lifestyles', which express the 'culture traits' of the 'colonial proletariat' whose relocation in the West Indies as a result of chattel slavery, had robbed them of their African 'essence' that which is dubbed as the 'Continuity-Creativity debate' 11 .

The major argument in the 'Continuity-Creativity debate' is based on a rather inflexible 'for or against position in regard to African cultural retentions' (Mintz \& Price, 
1992:viii). Firstly, we have the view of scholars who argued that the Africans had no recognisable cultures when they were conquered and 'civilised' by Europeans and if they did have any indigenous cultures, they were all but destroyed during the colonial experience. For this reason Papa Levi stated in one of his lyrics:

Them take way we name and call we nigger, the only words we know "I's ah coming massah", them tell we say we ignorant and inferior and how then intelligent and superior, through the complexion of them skin colour. (Papa Levi, Ghettotone Sound System, 1983)

Consequently and in line with Levi's suggestions, it was argued that a process of 'cultural stripping' was said to have occurred 'because Africa and Africanness were negatively valued, it was often assumed that no vestiges of his original culture could be left after the African was forcibly transferred to the New World" (Davis/Simon, 1983:26). Hence it was the uncritical acceptance of the master's values and institutions during the colonial era, that led to the Caribbean migrant having no say in their 'acculturation' and thus they were 'forced into accepting British Culture along with their servitude' (Rex and Tomlinson, 1979:291). Unsurprisingly the deviant 'life-style' as embraced by the 'teeny bopping' black youth is a direct consequence of their 'forced acculturation' and a seemingly valid explanation for their negative 'cultural traits'. For as Back and Solomos suggest, "the unwritten assumption is that minority populations and their children constitute a group which exhibit interesting, problematic and varied identities, while the identities of the majority are viewed as unproblematic" (Back and Solomos, 1996:132). Back and Solomos make known that the premise upon which this type of social analysis is founded is flawed as it posits a notion of Britishness as stable and 'unproblematic'. As such the differences between 'minority 
populations' are magnified and reified for the purpose of explaining these noticeable differences, in behavioural patterns, when measured against a stable British culture. This means that the observable differences in 'lifestyles' become the definitive factor in understanding the noticeable conflicts between the generations of West Indians who reside in Britain, especially on the terrain of music. However, it was suggested by Gilroy that the transformation of host communities by their exposure to black forms of popular culture is a consequence of how a 'musical culture supplies a great deal of the courage required to go on living in the present' (Gilroy 1993a:36). He further demonstrates how this is an 'organiser' of 'consciousness' and therefore cannot be separated from a tradition of struggle against oppression, which subsequently promotes black solidarity in the face of mainstream misrepresentation. This type of language use explains how the British Born deejays used Jamaican language (Patwa) to express an alternative perception of self, as contained in the Session-tapes that document the lesser-known dimensions of Reggae-dancehall culture. Therefore the 'voice' is a current manifestation of traditional types of African resistance to European cultural hegemony, 'in which music and song are conceived as ideological weaponry for survival' (Cooper 2000). Reggae music therefore becomes the cultural template through which performers consciously and intelligently express their innermost concerns, which suggests that:

We must not underestimate the ways in which our own experiences have generated ways of seeing the world that are insightful, innovative and more relevant to the challenges that we face based on our own experiences. Therefore, we need to be more confident when we deploy these self-generated concepts as they particularly speak to our own experiences. That does not mean that we accept our own categories without interrogation. What it means is that we recognise what it is they 
are trying to capture which has not been, in my opinion, accurately defined before. The deejays are giving us the functioning word, which we need to make flesh and give expression to; as we come out of an era of cultural reflection and analysis. (Rupert Lewis, author's interview, 2001)

An evaluation and subsequent rendering of the 'functioning word which we need to make flesh' enables a fuller consideration of these 'self-generated concepts' as the modes used to define and record historical experiences. However, in the next section I will offer an insight based on this form of 'cultural reflection that considers the role of 'cultural retentions', which are historically driven but quite often 'hidden' within the expressive culture.

\section{Black youth rebelling in the master's house}

Government pay Babylon just to harass, them love beat youth-man like Trevor Natch, and shoot people with them tear gas.

(Trevor Natch, Diamonds Sound System, 1984)

Several deejay accounts graphically depict what it was to be a member of a community that was/is on the receiving end of racial discrimination and the practical steps you take in order to maintain both your liberty and your sanity in a hostile environment. This sentiment is perfectly captured in Trevor Natch's lyric where he explains how many black youth viewed their social reality, as a consequence of a Thatcherite government that militated against them. Police beatings and harassment were commonplace and there were several police stations that during the 70s and 80s you did not wish to end up in South London - Lewisham, Carter Street, Brockley, Peckham and Brixton where they were known to go 'nigger hunting' ${ }^{12}$ and as a black youth, if arrested, you would probably get a good hiding. What then is of interest here is the coping mechanisms these youth deployed to combat their 'problem' status and the 
culture of resistance and transcendence that regenerated and updated this struggle for social justice. The fact that they realised that these 'problems', especially with the police, were in many cases not of their own making is relevant, because it shows how confronting adversity is a central feature in the deejay's performance. In fact according to Benji:

If you can put a sentence together, their (police officers) mannerisms change. The way they were taught has blighted them that's why they don't see us as individuals. They recoil if you can talk well...and I remember getting stopped by them in the early 80 s and they were shocked that I was a draughtsman and could afford a criss (new) car. Wanted to arrest me just for that, bredrin. (Papa Benji, Author's interview, 2000)

Benji suggests that it is necessary for many white racists who are in positions of power, in this case the police, to believe that black people are 'naturally' uneducable and is why he further suggested that 'the way they are taught has blighted them...they don't see us as individuals', which means their prejudice is fuelled by a notion of 'natural' black inferiority; a consequence of their socialisation in a racist society. However, when the expected levels of inferiority are not forthcoming 'they recoil if you can talk well', because for the racist authority figure this runs counter to their expectations and this simple observation speaks of the challenges black people faced on a daily basis in a racist society, for many have to constantly prove that they are nothing like the negative depictions that dominate popular culture and fuel a white racist imagination. Realistically this means that the attitudes and prejudices that are harboured by many 'ordinary' members of the white community, irrespective of class or political alliance, are as much a part of their psychological make-up as any other minority/majority social group.

The point is that to overcome both physically and psychologically those racialized constructs that compound your subordination by perpetuating your 'natural' inferiority, you 
must be firstly aware of their existence. Having this awareness provides the locus for a collective identity that can be used to strengthen your resolve when faced with crisis situations that in other circumstances may appear to be insurmountable. Furthermore, due to the lack of recognised distance between the audience and the performer, in the sense that anyone who had something to say could use this platform to do so, it was our collective duty as deejays to promote ourselves in a more positive light. I suggest that this is so because the deejay biographically documents an ongoing history in the present, through the medium of Reggae-dancehall music, which combines the performative with the informative in a reflexive way. By doing so they confront head-on the more unsavoury aspects of what it is to be treated as a social problem by those who are supposedly in a position to be less judgmental. What is crucial to my argument is that this was the historical moment when deejaying was at its most forceful, pushing the 'pen furiously' (Prah, 1992:15) to create tales of resistance and transcendence that gave a voice to the voiceless black youth in Britain. The inference is that the Reggae-dancehall is a space within which these alternative cultural politics are freely aired and readily discussed, by those who are otherwise excluded from this level of meaningful social dialogue within the recognised public arena. The development, articulation and subsequent promotion of this trenchant 'hidden voice', of the largely disgruntled black youth, spoke of the realisation that we were downpressed ${ }^{13}$ for various reasons.

Tackling the reasons this downpression, whilst gaining an insight to the culture is key to unlocking and revealing this aspect of the black British experience, is important for numerous reasons. Not least of all because there were far too many accounts, academic and journalistic, that depicted black youth as social pariahs whose 'celebration of a range of archetypal violent anti-heroes, Dirty Harry, Chuck Norris and the late Bruce Lee' (Cashmore and Troyna, 1982:33) explained why they would explode in acts of violence. Moreover for these theorists 
the main driver for explaining what causes black youth to behave in this way is traced back to their Caribbean ancestry, because there is said to be a "penchant for violence within the West Indian culture, possibly stemming from the days of slavery when the only method of retaliation was doing physical damage to the overseer, agent or even the slave-master" (Cashmore and Troyna, 1982:33). What this type of investment in the pathological black subject does is it limits the scope of their responses, to dealing with an ongoing history of white domination, to an overly deterministic notion of full compliance or rejection based on 'sudden violence'. The suggestion is that the slaves who did not 'retaliate' are representative of the 'parent culture', whose 'West Indian culture' is based on capitulation and deference. Whilst 'black youth', according to their rationale, display the disposition of the rebellious slaves who totally rejected the ways of the master class and explains the conflict situation they find themselves in with their parental generation. However, these restricted theorisations fail to recognise the cognitive strategies, which are grounded in the cultural retentions the oppressed employ to resist their 'structural placement' in a racist society.

For instance a highly significant Caribbean cultural retention which draws upon a West African cultural heritage is the ubiquitous employment of an orality based on antiphony, call and response ${ }^{14}$ in deejay culture. This method of social commentary comes from the West African Griot ${ }^{15}$ tradition, which was transferred to the digging songs the Africans would sing, whilst slaving on the sugar plantations in places like Jamaica. These digging songs which were the mainstay of cultural renewal and social survival, forged from the merging of their outlawed African tongues ${ }^{16}$ and the European melodies they were exposed to. For instance, the sailors shanties they heard during the notorious Middle Passage $^{17}$ journey as well as their exposure to Christianity and its associated ritual practices, the singing of hymns and Christmas carols etc. It was through the ongoing development and performance of these digging songs that the slaves achieved what Spencer (1995) calls a 
'mastery of form' and a 'deformation of mastery' (Spencer 1995:151). This suggests that the slaves had to master the situation but could not reveal such mastery for fear of punishment or death, because they were told they were free but knew they were not. That is why you will hear Jamaicans state that 'Babylon release the chain, but them ah use them brain', as during the historical moment we are discussing and in many ways until this day, many blacks liken their social position to that of a modern day slave. In fact Gilroy provides a partial insight for this mental attitude when he suggested that due to 'historical memory...the slave experience remains a central metaphor for the processes of work in general' (1987:201), a factor that was lost on theorists like Pryce who viewed the behaviour of black youth as fuelled by 'hustling' or other types of 'delinquency'. Indeed Pryce's view is oppositional to what was for Nketia 'the fundamental concept that governs music performance in African and African-derived cultures that serves to unite black people into a cohesive group for a common purpose' (1974:22). A notion that is endorsed by the deejay Dirty Desi who argues:

Me lay down in me bed Jahman me feel sleepy, me gal say to me, hey look Desi, me look pon the TV tell me what did I see, it was ah documentary about the SPG, the special police group innah Hackney, them interview police about street attacks, them say $95 \%$ is done by blacks, them show how the police patrol in van, and them show how them harass the poor blackman, you could ah pickpocket or ah Christian, with you Bible in you hand, you coming from church, the next thing you know you get stop for ah search, 
you coming from school an you on the go,

the bull (police) them want to search you from you head to you toe, so go.

(Dirty Desi, Ghettotone Sound System, 1983)

Desi's lyric perfectly captures the manner in which Pryce's inadequate theorisations did little justice to those who were on the receiving end of the government's policies to curb the menace that was the unwanted black presence. That is why Desi argues that it does not matter which 'lifestyle' you supposedly represent, 'pickpocket/Christian/schoolchild', the treatment you receive at the hands of certain white authority figures is much the same. Desi's argument demonstrates how as an oppressed community we utilise the medium of 'music as an avenue for the expression of group sentiments' (Nketia, 1974:22). As such these forms of resistant culture cannot be reduced to these distinctive and overly deterministic 'lifestyles'; for such analyses fail to recognise the dialogic component that is central to their very existence as modes of community expression and cohesion. Equally the platform Desi utilises to articulate his alternate claims is the Reggae Sound System that has been traced to the Dancehalls of Jamaica during the 'late 40s early 50s' (Clarke, 1980) and the subsequent migration of Jamaicans here from the early 50s established the medium here as a 'core institution' (Gilroy, 1987). Furthermore, as Gilroy posits "Sound system culture redefines the meaning of the term performance by separating the input of the artists who originally made the recording from the equally important work of those who adapt and rework it so that it directly expresses the moment in which it is being consumed, however remote this may be from the original context of production" (Gilroy 1987:165). Hence:

Reggae is not a yes music and that's why so many youths used it to chant down Babylon during the uprisings in the 80s. It's a militant music and it's a vibes music and it's a love music. And they don't want that because what 
we will be doing is opening people's eyes to reality and that's not the thing that they want. (Blacker Dread, author's interview, 2006)

Blacker Dread suggests that recognition of the significant role of the discursive nature of this cultural form cannot be overlooked as its basic function is to 'open people's eyes'. Thus for many black youth, who knew no other place as 'home', a conscious decision was made on the terrain of language to stake a claim for 'belonging' as we were not content to be the 'passive receptacles of the will of the enslaving other' (Cooper 1993:174). Simply put 'those who have the right to define are the masters of the situation' (Ture and Hamilton, 1992:36), thus to alter the situation there is a need to discover knowledge that enables you to define reality in your own words, on your own terms. Therefore, redefining and reconstructing the dominant language can only become a form of self-empowerment when the historical necessity of this type of 'relexicalisation' (Jones, 1986) is known. For as Bolinger suggests, much consideration is needed when evaluating the role of language in our contemporary societies because, "the influences of language on thinking and behaviour must be everywhere pretty much the same. The manifestations will reflect social differences more than fundamental linguistic ones" (Bolinger, 1990: ix).

I am advocating a fuller appreciation of how the differences between groups that evidently share the same 'language' are social/cultural constructs, which subsequently become racialised and politicised. In other words you cannot stake your alternative claims through the language of your oppressor, unless you recognise the role that language has played in your historical oppression. Consequently on the usage of the word black as a unifier during the 70s and $80 \mathrm{~s}$ it was stated that "for all his efforts, indeed his achievements, he knows he is black: that colour is part of his identity and he knows that this will ultimately affect his life chances. And this gives him a sort of unity even if he does not wish to acknowledge it" (Cashmore and Troyna, 1982: 28). Markedly so when we consider the 
blanket condemnation of 'black youth' after the 1981 riots as “Lord Scarman's report in the first phase of the riots in Brixton is a crucial document in the history of this discourse on the black community. It set the official seal on a definition of black crime and tied these to what were felt to be distinct patterns of politics and family life, characteristic of black culture" (Gilroy 1987:104). Gilroy suggests that although it was 'black youth' that were regarded as the 'problem', it was the parents or guardians who lost 'control' of their offspring, due to the 'weakness of Afro-Caribbean communities' (Lawrence, 1982:100) who were to blame. This notion of the characteristic - read - weaknesses of black culture fed directly into what Willis described as 'patterns of racial culture' (Willis, 1977:47), which represent the blurring of the distinctions between 'formal' (the State) and 'informal' (commonsense) ideas on racialised attitudes. Crucially the blurring of the distinctions between formal and informal racism, assisted the depiction of black youth as deviant and their parental generations as weak. This perspective masks the memory of how a common historical experience equips black people with the necessary 'shared cultural codes' or coping mechanisms, by providing 'narratives from the past' (Hall, 1993:394), that deal with everyday life in a racist society.

Simply put, it is not enough to recognise the existence of Hall's 'cultural codes' if the necessity for them as anti-hegemonic devices is overlooked, as the messages contained therein contribute to these ongoing histories. These histories contain elements that are in a constant state of flux because a personal narrative becomes something else once it is shared in a particular type of 'social arrangement'. In fact it is during these moments of sharing our 'self understanding', deejays telling life-stories in the Reggae-dancehall, that the oppressed can recognise themselves within the grand narratives of the African Diaspora. For the overall message is one of a commonality of condition with regard to the positioning of the black 'other' in a white dominated racialised arena, which has gained most of its currency by devaluing the 'black experience'. This means that explanations that are too reliant on 
'symbolic escapism' or 'lifestyles' that foster 'false consciousness', which further mutes the lived reality of black people, are untenable as they deny the history of resisting and transcending white racism. For this reason in the next section I will focus on the deejay 'performance' as a mode of response to racial profiling and social injustice, thereby demonstrating how this notion of resistance and transcendence plays out in these alternative public arenas.

\section{Rastafari and black youth resistance}

Me never learn bout Africa from no preacher, me never learn bout Africa form no teacher, me say me learn bout Africa, from some true Ratsa, like me sister Asher, Cosmo and Shaka. (Lezlee Lyric, Ghettotone Sound System, 1983)

In the context of British society, the 'performance' that is being considered here contains dialogues that traverse the African Diaspora and are based on the acquisition of 'oral skills' in a Creolised language, which then act as a mode of response to the imposition of European culture on non-European peoples. As we shall see below one way of doing so was through formal education or religious instruction, which is why I have cited a few lines from a lyric I wrote about learning nothing of note about being 'black or African in church or at school' ${ }^{18}$. As a consequence of this lived reality many descendants of the African chattel slave are resistant to their general historical depiction as the antithesis of the European. Consequently resistance is most evident in the contested spaces, which are constructed around specific types of language usage, that express an alternative black subjectivity that does in fact bridge the intergenerational gap within black communities. The reason for staking this claim is the fact that this notion of language contends that a person who is familiar with the linguistic 
form has access to its alternative, self and communally empowering, claims by identifying with the worldview it expresses. Thus individual agency can interact with a collective representation to create a mechanism for promoting a level of awareness, which subsequently perpetuates directed defiance against a perceived oppressor. More so when we consider that in the case of the black British, the languages that are used for resistance have a largely standard English lexicon, which means 'the common English orthography base makes the idiosyncratic systems mutually intelligible' (Cooper 1993:12).

The utilisation of these linguistic forms, both oral and scribal, continues the type of 'pan Caribbean consciousness' (James, 1993) that was necessary for the Windrush Generation's ${ }^{19}$ survival, which was passed down to the generations that were born in Britain. Therefore many of deejays realised that the world view expressed through a usage of Standard English in everyday discourse, largely reduced them to the voiceless passive victims of a Eurocentric historical bias. Therefore, by blending several aspects of Jamaican oral culture with their own local argot, these deejays were to verbally present critiques of certain entrenched ideas; for instance, poesy as an exclusively white domain. This type of engagement was exemplified in the chorus of a lyric that was performed on Diamonds Sound System by the British deejay Papa Benji (1984), where he suggested that "poetry me better than Shakespeare, and me voice gone clear everywhere'. Benji's claim demonstrates how Sound Systems act as the main conduits for the transcultural dialogues that keep the various black communities in-tune with each other across the 'black Atlantic' (Gilroy 1993a). This means that the deejays become the veritable keepers of memories, for once the word is performed, recorded and disseminated it becomes an artefact; a historical document. Crucially this enables the performers to present their own arguments, in their own words and on their own terms, in a 'commonly agreed language' (Small, 1987:290) that counters their social problem status. Thus: 
In this sense young black men like myself in the 70's were associated with the dangers of the future; pessimism, dirt and noise, which was also a way of controlling the thoughts and actions of the black communities in Britain whose parents, we are told, failed to control their children. Yet by using our voices we presented counter narratives that at least made us aware that we were going through certain things because we were black.

(Ronnie McGrath, author's interview, 2001)

McGrath's argument is relevant because these 'counter narratives' presented an alternative account of what it meant to be a black youth in Britain during this moment from the deejay's perspective. For instance, this was the case when Papa Levi critiqued the ideological clout of 'Live Aid' by stating, "Bob Geldof song everybody start sing, through them dip innah them pocket an give we ah shilling, Europe left my people starving” (Papa Levi, Saxon Sound System, 1985). The act of rejecting 'Live Aid' in Papa Levi's lyric demonstrates how this 'hidden voice' refused to accept the existing frameworks, and their concomitant knowledges, for debating such issues. He quite rightly makes known that European acts of philanthropy, 'give we a shilling' should be treated with utmost suspicion by Africans as in this case they deny history. For to merely suggest that 'Europe left my people starving' will perhaps encourage those who are exposed to these words to seek out more information on such matters, which in many cases meant asking the performer exactly what they meant after their performance. This is because there was no physical distance between the performer and the audience in Reggae sessions and it is not unusual for members of the audience to reason with them about what they have suggested and obviously this enables the deejay to further explain their position. In fact Levi informed me that “this lyric was inspired by Walter Rodney's How Europe Underdeveloped Africa ${ }^{20}$. After me read that book me see Geldorf and them people in a completely different light" (Papa Levi, author's interview, 1994). More importantly, hardly 
anything in our (blacks and whites) general socialisation does anything to curtail this distorted view, in fact the manner in which we are educated/socialised exacerbates the tension between the 'races', reinforcing this distorted view of what it means to 'belong' to history. This is why the deejay would often seek approval and encouragement from their audience, as they uncovered and exposed the brutality of a racist society through tales that were recognisable to those who shared these experiences, which is why Dirty Desi argued:

Cau flash it oppah, ${ }^{21}$ roots an culture,

maggie tatcher, even labour, either either, blackman suffer, under pressure, call we nigger, cannot prosper, no job offer, become hustler, could ah mugger, or bag snatcher, sometime burglar, even daughter, ah turn stripper, could ah beggar, even worsah ${ }^{22}$, police capture, lock in panda, sometime rover, cannot wonder, judge don't jester, make we prisoner, even lifer, under jailer, baldhead Rasta, what we prefer, Etee-opia or turn chanter, for high power, lord. But if you happy an you love it say forward! (Dirty Desi, Ghettotone Sound System, 1983)

Dirty Desi argues that our oppression is perpetual as it is governmentally determined that we (black people) 'suffer', regardless of who happens to be in power, 'maggie tatcher, even labour'. That is the main reason why we 'cannot prosper', for how can one prosper without any 'job offer'? This he suggests partially explains why many of us do in fact 'become hustler, mugger, burglar, even daughter (woman) ah turn stripper'; thus the behaviour is not driven by default for being born black, but perhaps by circumstances that militate against you for being born black. . This take on certain acts of desperation suggests that they are not merely a pathologically determined black problem, for Desi points out that sometimes people under pressure will do what they deem necessary to survive. Moreover, Desi's account 
refutes the notion that there was a blanket rejection by 'black youths' of any type of meaningful integration into the mainstream society, due to an unwillingness to adhere to socially acceptable forms of behaviour. That is why he suggests that we 'cannot wonder', as in thinking through our predicament to ascertain why we are so victimised during the physical act of 'wandering', looking for employment when as a black person the likely result will be 'no job offer'. Moreover, when I invited Desi to explain the rationale for writing this lyric during that historical moment he suggested:

When I wrote these types of lyrics I was studying and spent a lot of my time thinking through my situation, because I remember my girlfriend's brother was unemployed and was always getting stopped by the police even though he spent most of his time looking for a job. One time they even locked him up on a mistaken ting and it made me realise how vulnerable I was. That's why I thought my only choice was to chat about these things and make people aware, cos I had no intention to go to Ethiopia, God know. (Dirty Desi, author's interview, 2001)

The last part of Desi's account is particularly interesting for he makes it clearly known that his intention was to stand-up and fight his corner in the UK, as for him the notion of looking for better in Ethiopia ${ }^{23}$, was unrealistic. This is why he argued 'baldhead Rasta, what we prefer, Etee-opia or turn chanter, for high power', thereby presenting another option for those who would 'prefer' to 'turn chanter for high power' and voice these concerns on Sound Systems. The idea of representing the 'high power' is, in the first instance, recognising the role of the Sound System as providing the amplified platform for a voice that acts as a medium for change. Secondly, it is also a manner in which we can carry out the 'works', as inspired by our belief in the divine as the 'higher power' because as Desi suggests 'God 
know'. That is why 'Etee-opia', was a metaphor to make black people aware of their African roots, because as a globally oppressed other we need to unify in the struggle against our common enemies.

I wish to point out here that this did not mean that you had to physically relocate to this geographical region in your endeavours to overcome the Babylon system, because Reggae is for everyone on the planet who requires this 'soul food' but its African roots must be recognised, in much the same way as the presence of the Almighty in our lives as human beings. That is why Rastafari in Britain, especially during the 1970s and 1980s, made the presence of God in the likeness of H.I.M. Emperor Haile Selassie more palatable to the black youth who were experiencing rejection in the land of their birth. By embracing a Rastafari worldview black youth in Britain were introduced to an active God and Christ like character that was more akin to the revolutionary Jesus; the 'God Of The Rahtid'24; not the passive 'gentle Jesus meek and mild' that seemed to appeal to their parents' generation. This was a main feature in the manner in which Hebdige suggests Rastafari took the Bible and flung it 'back rude', exemplified through their recognition of the power and manipulation of the spoken word. Yet for black youth, according to Cashmore and Troyna, their rejection of conventional Christianity led to 'profound behavioural consequences' which were evidenced in the embracing of a 'stylised Jamaican patois, a language of fictive kinship' (Cashmore and Troyna 1982:73) that was transmitted through the culture of Rastafari. They suggest that black youth accessed the Rastafari worldview through the medium of Reggae music which, as previously suggested by Pryce, provided the 'social opening' that welcomed their 'expressive-disreputable orientation' (Pryce (1979:154). What this meant was that black youth in Britain were now 'drifting' under the 'influence' of Reggae into 'Rasta peer groups' with an 'acceptance of Haile Selassie as God' (Jones, 1986:61). A perspective that makes perfect sense in light of a call by one of the major influences on Rastafari, Marcus Mosiah 
Garvey in 1937, for black people to 'emancipate themselves from mental slavery, this being a major responsibility for themselves and themselves alone' (Nettleford, 1998:313). In line with Garvey’s recommendation Macka B suggests:

If you wait for another man to save you will never do anything for your self. God has given me this gift and the talent to speak and people find it interesting and listen. I cannot therefore abuse that talent... Reggae music is like a vehicle for me to right certain wrongs cos sometimes you just have to do what you have to do no matter about the consequences, cos people don't care about what they do to us. (Macka B, author's interview, 2002)

Macka B's argument demonstrates why we cannot overlook the significant role religious forms play in the formulation and reformulation of the social, cultural and political sensibilities of these young men and women. To do so simplifies the role the Bible/God has played, and still plays, in the psychological make-up of the generations of peoples of the African Diaspora and is why he suggests his 'gift' is from 'God'. This means that we must continuously acknowledge the manner in which the historical experience of chattel slavery is totally relevant to any understanding of black musical expression within these alternative public arenas. For as Alleyne suggests, the merging of African and European religious forms with music and dance was a key factor in unifying the slaves in Jamaica, 'because they were major instruments of cohesion and revolt' (Alleyne, 1988:118). This type of merging is, according to Spencer, not unusual for peoples of African ancestry as it is akin to an African notion of spreading or transmitting a "social gospel" (Spencer, 1995:68), which dealt with real earthly problems. The religious message has to be conveyed in a manner in which the people could truly recognise their lived reality, and more importantly actively participate as part of a conscious collective effort to remedy the negative aspects of this ongoing reality. 
Hence irrespective of age, Africans on the continent and their descendants throughout the Diaspora were, and many still are, expected to partake in 'religious ceremonies', because 'African religious traditions take into consideration not only one's intellect, but also one's emotions, the mental and the visceral' (Barrett, 1988:27). For it is part of the deejay's role and purpose as spokesperson for the community to 'release within the people a feeling of power' (Barrett, 1988:27) over the negative aspects of everyday living during the cathartic moment that is the deejay performance. This demonstrates how black music is a vehicle for the dissemination of these 'hidden voices', as it provides a space for the deejays to partake in a Diasporic system of intellectual exchange. Thereby placing their lyricism in an outernational $^{25}$ context because the language of choice, Patois, and the worldview it represents cannot be geographically bounded. This means that the deejays consciously challenged the notion that they should be expressing themselves in Standard English, because this is the language that they would be formally educated in. This point is made by Wong (1986) who argued that black youths resisted their mother tongue's 'alphabet of terror', by embracing Rastafari language and symbolism ${ }^{26}$. However the idea of being responsible for your own destiny and immediate fate was missed by many theorists who saw Rastafari as an escapist movement, based on anthropological notions of millenarianism 'where solutions are religious rather than revolutionary' (Hebdige, 1979:426). More importantly, Cashmore regards these factors as definitive in the self imposed exile of black youth from the wider black community, because usurping the white Jesus of Christian orthodoxy and replacing him with a black godhead, only increased the generational gap. Moreover, the conflation of Rasta/rudie/Reggae as 'delinquent subcultural, solutions' (Brake, 1980:27) further places an emphasis on external manifestations of style which means the substantive nature of the resistant form is lost. Thus dreadlocks, the wearing of red, gold and green colour symbolism, language usage and listening to Reggae music, become the chief determinants in recognising 
the deviant black youth. Hence 'rebellion has become a solution, a sub cultural style stretching from reinterpretation of Rasta, to street crime and 'voluntary unemployment' (Brake, 1980:27).

The emphasis was clearly on the idea that black youths not only render themselves unemployed and thus opt for a life of street crime; they also valorise their difference by openly displaying Rastafari symbolism. Furthermore, Cashmore and Troyna, in agreement with Brake, suggest that 'hustling' and 'pimping' and other forms of 'street crime' are the 'easy options' that black youth employ as their main 'strategies of survival' (Brake 1982:32). This meant that there was a tendency in this perspective to reduce the "political scope of the movement' (Gilroy, 1982:293) and ignore the consequences of the 'structural placement' of black people in a racist society. With this in mind, Brake's suggestion that black youth are unemployed by choice becomes highly problematic and reinforces the notion of a culture of 'black' street crime. For as Gilroy suggests 'we must resist the equation of Rasta politics with work refusal' (1982:293), as well as the depiction of Rastafari as an escapist youth cult, which uses Reggae music to maintain its distance from the wider community

Without this type of understanding of the profundity of Rastafari consciousness the culture and its advocates will forever be misrepresented by those who fail to appreciate that it is not about escapism. Rather it is about learning why as Africans we are in this situation and then using that knowledge to determine what can be done to transcend our predicament, as in many black communities 'religion is a total involvement...not a mental exercise' (Barrett, 1988:27). Therefore, recognising an exposure to black Christian styles of worship, especially black Pentecostalism which provided 'one of the only safe spaces where black identities were celebrated and perpetuated' (Beckford 1998:26), as well as charismatic leadership, provides a template for re-thinking the role of religious belief in counter-cultural spaces. That is why black youth, and many white youth, were ready to receive the libratory message when 
confronted with the 'oral skills' of the deejays on the Reggae Sound Systems that dominated the black communities in Britain during that moment. Moreover, it was suggested by Gilroy, that the transformation of host communities by their exposure to black forms of popular culture is a consequence of how a "musical culture supplies a great deal of the courage required to go on living in the present' (Gilroy 1993a:36). Gilroy demonstrates how the alternative worldview made manifest in the marriage of the Rastafari message and Reggae music, as an 'organiser' of 'consciousness', cannot be separated from a tradition of struggle against oppression. In the case of Reggae music, this 'tradition of struggle' is maintained because it was/is 'protected' by a 'language, a colour and by a culture which had been forced to cultivate secrecy against the intrusions of the Master Class' (Hebdige, 1979:434). This is why these cultures often resist the 'outsider's' gaze because, as I suggested above, this is one aspect of how black music creates an alternative space for those who view their ongoing oppression as a consequence of white domination. What I am arguing is that black youth utilised this alternative space to air and discuss their innermost concerns, socially, culturally, politically and spiritually in a language they owned and controlled as evidenced in the following where the British deejay Lane G explains to her audience:

Rahbit, hear me now star, Jesus Christ, Jesus hear me now. Anybody know what's happening June the 9th (1983)? June the 9th man come on come on, what's happening June the 9th? Election alright Election Champion hear me now; eh hear me now star.

Election, is ah damn election, rahbit, election is a damn election, them ah go figure out who ah go run the land, say don't vote Margaret she's a wicked woman, let's all get together an think as one, Vote Labour, Labour, that way we'll be safer, safer, if we all vote Labour. 
Four years ago we vote Conservative,

answer one question about what did they give,

3 million unemployment an nowhere fi live,

I beg you tell me is that progressive,

Vote Labour, Labour, that way we'll be safer, safer, if we all vote Labour.

If you want keep you job vote Labour, Labour,

if you want ah few bob vote Labour, Labour,

Labour we ah goh vote fah, we ah go vank (vanquish) Margaret Thatcher,

rahbit. (Lana G, Sir Lloyd Sound System, 1983)

Lana G's comments as to why black youth should vote against Thatcher and her Tory Government crucially cites the notion that we will be 'safer' under a labour government'; 'safer' because we will be more likely to 'keep our jobs' and 'safer' from the policies that gave rise to our continued oppression. Consequently Lana $\mathrm{G}$ receives a rapturous ovation as the youth, who are present in the Reggae-dancehall can identify with her political stance, because 'tatcher's' Tory government were deemed to be the worst enemy of the black community. Therefore by expressing disapproval of the system in this fashion, deejays do in fact provide black youth with collective/alternative modes of thought and action, which determine how these performed choices and behavioural patterns manifest as the 'hidden' voice'. Moreover, the notion of choice was strategic, as this 'hidden' dimension of urban black consciousness was not restricted to the ruling political party due to the realisation that 'either either, blackman suffer' as Dirty Desi argued above. That is why the manner in which Lana $\mathrm{G}$ weighs up the pros and cons of which party to vote for in her lyric, with regard to the real chances of employment and public safety for the black community whether young/old, male/female in the recognised public sphere, was for black youths a major concern, during this historical moment, as we often knew no other place as home. 


\section{Conclusion}

In this discussion I have considered how access to an alternative worldview, as provided through the medium of black music, provides a space where the African Diaspora can think themselves into being in a more conscious fashion than has been previously recognised. This was demonstrated by describing how there is in the history of deejaying in Britain a 'struggle to maintain communities', which not only transcend, but also transform their racist 'host' communities, by bringing certain aspects of the struggle to the fore. This is based on a shared sense of oppression/exclusion, because 'our imaginations are conditioned by an enduring proximity to regimes of racial terror' (Gilroy 1993a:103). The suggestion is that black music often speaks to the experiences of non-white peoples in a racist society, and thus furnishes a site for various types of inter/intra cultural exchange. For this reason it is the 'moral aspects' of black music that need to be considered, especially with regard to 'the ethical value of the music and its status as an ethnic sign' (Gilroy 1993a:36). Hence the fact that those who the music speaks to can recognise the message, is crucial to my argument about why black youth used the form in Britain to debate and discuss our own 'problem' status during the 70s and $80 \mathrm{~s}$ in a language we belonged to. Therefore how the musical form is validated and authenticated is generated from within the culture and cannot be geographically bounded because it is a 'route of cultural exchange' and an outernational voice of the black struggle against white domination; that needs to be appreciated as such in any evaluation of the efficacy of counter-cultures. This is why these cultures often resist the 'outsider's' gaze because, as I suggested above, this is one aspect of how black music creates an alternative space for those who view their ongoing oppression as a consequence of white domination.

\section{Bibliography:}

Alleyne, Mervyn. (1988), Roots of Jamaican Culture, London: Pluto Press. 
Back, Les. \& Solomos, John. (2001), (eds), Theories Of Race And Racism: A Reader, London: Routledge.

Barrett, Leonard. (1988), The Rastafarians, Boston, USA: Beacon press.

Beckford, Robert. (1998), Jesus Is Dread: Black Theology and Black Culture in Britain, London: Darton, Longman and Todd.

Bolinger, Dwight. (1980), Language the Loaded Weapon: the use and abuse of language today, London: Longman.

Brake, Mike. (1980), The Sociology of Youth Culture and Youth Subcultures, London: Routledge \& Kegan Paul.

Campbell, Horace. (1985:14) Rasta And Resistance from Marcus Garvey to Walter Rodney, London: Hansib Publishing Ltd.

Cashmore, Ernest. \& Troyna, Barry. (1982) (eds), Black Youth In Crisis, London: George Allen \& Unwin Publishers.

Clarke, Sebastian. (1980), Jah Music: The Evolution of the Popular Jamaican Song, London: Heineman Educational Books.

Cooper, Carolyn. (1993), Noises in the Blood: Orality, Gender and the 'Vulgar' Body of Jamaican Popular Culture, London and Basingstoke: Macmillan Education Ltd.

Cooper, Carolyn. (2000), "Rhythms of Resistance": 'Jamaican Dancehall Culture and the Politics of Survival' (Unpublished Paper received via email, September $\left.29^{\text {th }} 2000\right)$.

Davis-Palmer, Yvonne. (2005) 'Narratives and the cultural construction of belonging in Sligoville' (in) Besson, Jean \& Fog Olwig, Karen, Caribbean Narratives of Belonging: Fields of relations, sites of identity, Oxford: Macmillan Education Ltd.

Davis, Stephen. \& Simon, Peter. (1983) Reggae International, London: Macmillan Press Ltd. Finnegan, Ruth. (1970)_Oral literature in Africa, Oxford: Oxford University Press Garvey. Amy, Jaques. (1986) The Philosophies \& Opinions of Marcus Garvey: Or Africa For 
The Africans, Mass USA: The Majority Press

Gilroy, Paul. (1982), 'Steppin out of Babylon' in CCCS, The Empire Strikes Back, London: Routledge.

Gilroy, Paul. (1987), There Ain't no Black in the Union Jack: The Cultural Politics of Race and Nation, London: Hutchinson Education.

Gilroy, Paul. (1993a), The Black Atlantic: Modernity and Double Consciousness, London: Verso.

Gilroy, Paul. (1993b), Small Acts: Thoughts On The Politics Of Black Cultures, London: Serpents Tail.

Hall, Stuart. (1993), 'New Ethnicities' (in) Morley, David. Kuan-Hsing, Chen. \& Hall, Stuart (eds), Critical Dialogues in Cultural Studies, New York: Routledge.

Hebdige, Dick. (1979) Subculture: The Meaning of Style, London: Methuen.

James, Winston. 'Migration, Racism and Identity Formation: The Caribbean Experience in Britain', (in) James, Winston. \& Harris, Clive. (eds) (1993), Inside Babylon: The Caribbean Diaspora In Britain, London: Verso.

Jones, Simon. (1986), White Youth And Popular Jamaican Culture, PhD thesis for Centre for Community and Urban Studies, Faculty of Arts, University of Birmingham.

Lawrence, E. (1982) 'In the abundance of water the fool is thirsty: sociology and black pathology’ (in) CCCS, The Empire Strikes Back, London: Routledge.

Lea, John. \& Young, Jock. (1984), What is to be done about law and order?, Harmondsworth: Penguin.

Mintz, Sydney, Wilfred. \& Price, Richard. (1992), The Birth Of African-American Culture, Boston, USA: Beacon Press. 
Mintz, Sydney, Wilfred (1989), Caribbean Transformations, New York: Columbia University Press.

Morris, Mervyn. (1999), Is English We Speaking and other essays, Kingston: Ian Randle Publishers.

Nettleford, Rex. (1998) “Discourse on Rastafarian Reality” (in) Murrell, Samuel. William D. Spencer, \& McFarlane, Adrian Anthony, (eds), Chanting Down Babylon The Rastafari Reader, Kingston, Jamaica: Ian Randle Publishers.

Nketia, Kwabena. (1974), The Music of Africa, New York: W.W. Norton.

Prah, Kwesi, Kwah. (1992) Capitein: A Critical Study Of An $18^{\text {th }}$ Century African, Trenton, NJ: Africa World Press.

Pryce, K. (1979), Endless Pressure: A Study of West Indian Lifestyles in Bristol, Harmondsworth: Penguin.

Pryce, K. (1986), Endless Pressure: A Study of West Indian Lifestyles in Bristol, ( $2^{\text {nd }}$ ed), Bristol: Bristol Classical Press.

Rex, John. and Tomlinson, Sally. (1979), Colonial Immigrants in a British City: A Class Analysis, London: Routledge.

Rodney, Walter. (1981) How Europe Underdeveloped Africa, Washington DC, USA: Howard University Press.

Spencer, Jon. Michael. (1995), The Rhythms of Black Folk: Race, Religion and PanAfricanism, Trenton, NJ: Africa World Press, Inc.

Small, Christopher. (1994), Music of the Common Tongue, London: Calder.

Staple, Neville \& McMahon, Tony (2009) Original Rude Boy: From Borstal to the "Specials" - A Life in Crime and Music, London: Arum Press Ltd. 
Ture, Kwame. and Hamilton, Charles, V. (1992), Black power: The Politics of Liberation in America, USA: Vintage Books.

Willis, Paul. (1977), Learning to Labour, London: Saxon House.

\section{Author's interviews}

Asher Senator, April 29 1999 , London, England.

Blacker Dread, March $8^{\text {th }}$ 2006, London, England.

Dirty Desi, November $2^{\text {nd }} 2001$, London, England.

Macka B, October $23^{\text {rd }}$ 2002, London, England.

Papa Benji, July $23^{\text {rd }}$ 2000, London, England.

Papa Levi, December $21^{\text {st }} 1994$, London, England.

Ronnie McGrath, December $13^{\text {th }} 2001$, London, England.

Rupert Lewis, May $6^{\text {th }} 2001$, Kingston, Jamaica.

\section{Session-tapes:}

Ghettotone Sound System, $24^{\text {th }}$ September, 1983, London, England: Dirty Desi, Lezlee Lyrix \& Papa Levi.

Sir Lloyd Sound System, $28^{\text {th }}$ May 1983, London, England: Lana G.

Diamonds The Girls Best Friend Sound System, $4^{\text {th }}$ August 1984, London, England: Papa Benji \& Trevor Natch. 
Notes

[1] Sound Systems cannot be reduced to a 'large mobile disco' (Gilroy 1987), as there is an aesthetic value that far transcends any such description. Additionally a Sound System is also known as a Set, or The Set, probably because you have to 'set-up' and 'string-up' (wire up the amps, speakers etc.) before you can play them. See Gilroy (1987:164/66) There Ain't No Black In The Union Jack, for a comprehensive description of Sound System aesthetics.

[2] Deejays in the Jamaican sense are akin to MCs or rappers. They are not to be confused with DJ's (Disc Jockeys) who play records. See Henry (2006) What the Deejay said: a critique from the street, London: Learning By Choice, for an in depth analysis of deejay culture.

[3] See for instance Gilroy "After the love has gone": bio-politics and ethno poetics in the black public sphere, Public Culture, 1994, Vol 7: 49-76.

[4] The Rastafari worldview and doctrine are presented in great detail in Barrett, Leonard (1988), The Rastafarians, Boston, USA: Beacon Press \& Clarke, Sebastian. (1980), Jah Music: The Evolution of the Popular Jamaican Song, London: Heineman Educational Books.

[5] See Martin (1986), Race First: The Ideological and Organizational Struggles of Marcus Garvey and the Universal Negro Improvement Association, for an overview of Garveyite doctrine.

[6] Jamaicans will often tell you they speak Patwa and not patois and will more often than not spell it this way. See Morris (1999:46/47), 'printing the performance' where he explains more about this process of language and self reclamation. Morris, 
Mervyn. (1999), Is English We Speaking and other essays Kingston: Ian Randle Publishers.

[7] These taped sessions are generally recorded on cassettes and have since the late 1970s been commonly known as 'Yard (Jamaican) Tapes'. However, from the early 1980s other points in the African Diaspora began to partake in these exchanges, which by this time also included Video cassettes as well, most notably from Britain, the USA and Canada. These recordings are known as 'Session-tapes' within the culture as they do not come from Yard (Jamaica) and that is what is meant by the term here.

[8] Deejays call our compositions lyrics as opposed to poems or songs; hence we 'chat lyrics' on Reggae beats.

[9] See for instance Davis-Palmer (2005:44/65) 'Narratives and the cultural construction of belonging in Sligoville', where she details the history behind how this kinship process gave birth to 'Sligovillians' within the Parish of Spanish Town, Jamaica. (in) Besson, Jean \& Fog Olwig, Karen, Caribbean Narratives of Belonging: Fields of relations, sites of identity, Oxford: Macmillan Education Ltd.

[10] For further insight as to the influence of Jamaican Rude Boy culture on wider British youth culture, see (2009) Original Rude Boy: From Borstal to the "Specials" - A Life in Crime and Music, Neville Staple \& Tony McMahon, London: Arum Press Ltd.

[11] See Besson, Jean. \& Chevannes, Barry. (1996) 'The continuity-Creativity Debate:' New West Indian Guide, Vol 70 no $3 \& 4$.

[12] See The Battle for Brixton (2006, Blast Films) where you will witness a police officer confessing that he went 'nigger hunting' with fellow officers in Lambeth during the 70 s and 80 s. 
[13] Rastafari state that your enemy presses you down and therefore is a 'downpressor'.

[14] Call and response is basically a leader singing the main body of a song (the call), aided by an alternating chorus type response from the audience (the refrain) which represented a comment on the leader's theme. The call and response format is also used by groups of drummers (widely outlawed during the plantation slave era) who would assume the role of lead and chorus. This usage of call and response originates from the communal pattern of West African social commentary, which enabled the community to voice their opinions as a functionally expressive part of a greater artistic whole.

[15] Griots are West African social commentators who can be hired to sing about various issues or even individuals. For a more detailed analysis see Finnegan, Ruth. (1970) Oral literature in Africa, Oxford: Oxford University Press.

[16] For more on this notion see Campbell, Horace. (1985:14) Rasta And Resistance from Marcus Garvey to Walter Rodney, London: Hansib Publishing Ltd.

[17] The Middle Passage was the route that was used to transport chattel slaves from Africa to North America. It was one aspect of the triangular trade that linked Europe, with the Americas and Africa for over four hundred years.

[18] See Henry (2007) 'Too blak for your own good; Head-decay-shun' (in) Whiteness Made Simple: stepping into the grey zone, London: Learning By Choice.

[19] On June 22 1948, former troopship the Empire Windrush docked in the port of Tilbury, Essex with nearly 500 passengers, mostly from Jamaica, on board. The arrival of the ship marked the beginning of large-scale West Indian immigration to Britain, changing the country's social landscape forever. http://www.telegraph.co.uk/ $\underline{\text { Windrush-generation.html }}$ 
[20] Rodney, Walter. (1981) How Europe Underdeveloped Africa, Washington DC, USA: Howard University Press.

[21] The 'Oppah' is the Sound System Operator who would play the records that were given to him by the selector who was responsible for the music that was played on the night.

[22] Common Jamaican term used for worse than.

[23] During this historical moment there were many advocates of Rastafari who would use Reggae as a medium to encourage people from the African Diaspora to return to the Holy Land of Ethiopia and many Rastafari now live in Shashemene. For examples of the Rastafari take on repatriation, see Chevannes, Barry. (1994:248/9) Rastafari: Roots and Ideology, New York: Syracuse University press.

[24] See Beckford, Robert, (2001:31/36) 'God of the rahtid: redemptive rage', God Of The Rahtid, London: Darton, Longman and Todd Ltd.

[25] Outernational is a Jamaican term that has been used in Reggae circles for decades and basically suggests that the influence of the music and culture transcends geographical boundaries.

[26] See Nettleford, Rex. (1998) "Discourse on Rastafarian Reality” (in) Murrell, Samuel. William D. Spencer, and McFarlane, Adrian Anthony, (eds), Chanting Down Babylon The Rastafari Reader, Kingston, Jamaica: Ian Randle Publishers. 